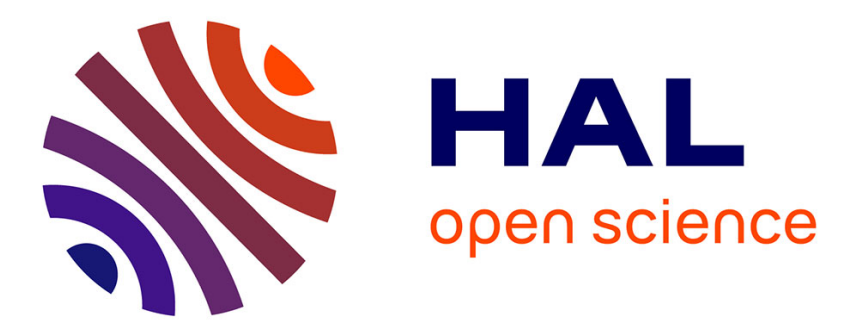

\title{
Relative importance of management and natural flooding on spider, carabid and plant assemblages in extensively used grasslands along the Loire
}

Denis Lafage, Julien Pétillon

\section{- To cite this version:}

Denis Lafage, Julien Pétillon. Relative importance of management and natural flooding on spider, carabid and plant assemblages in extensively used grasslands along the Loire. Basic and Applied Ecology, 2016, 17 (6), pp.535-545. 10.1016/j.baae.2016.04.002 . hal-01302406

HAL Id: hal-01302406

https://hal-univ-rennes1.archives-ouvertes.fr/hal-01302406

Submitted on 14 Apr 2016

HAL is a multi-disciplinary open access archive for the deposit and dissemination of scientific research documents, whether they are published or not. The documents may come from teaching and research institutions in France or abroad, or from public or private research centers.
L'archive ouverte pluridisciplinaire $\mathbf{H A L}$, est destinée au dépôt et à la diffusion de documents scientifiques de niveau recherche, publiés ou non, émanant des établissements d'enseignement et de recherche français ou étrangers, des laboratoires publics ou privés. 
36 Relative importance of management and natural flooding on spider, carabid and plant

37 assemblages in extensively used grasslands along the Loire

39 Denis Lafage ${ }^{\mathrm{a}, \mathrm{b}, *} \&$ Julien Pétillon ${ }^{\mathrm{a}}$

40

41 anniversité de Rennes 1, EA 7316, 263 Avenue du Général Leclerc, CS 74205, 35042 Rennes

42 Cedex, France

43 b'Université d'Angers, LUNAM, GECCO, 2 Boulevard Lavoisier, 49045 Angers, France.

$45{ }^{*}$ Corresponding author; Email: lafage.denis@gmail.com, tel: +33 611497736

46

47 Running title: Efficiency of AES in flooded meadows

48 Word count: $\mathbf{5 1 2 4}$

49

* $\quad$ Corresponding author. Tel.: +33 228205167; fax: +33 228205075.

E-mail address: lafage.denis@gmail.com. 
52 In Europe, agri-environment schemes (AES) have been implemented to counteract the effects of

53 agricultural intensification. Studies investigating the role of management improvement induced by

54 AES are quite numerous, but rarely take into account the effect of natural perturbations such as

55 flooding, although severe disturbances are well known to shape community structure. Here we

56 investigated the relative importance of management improvement and flooding to explain

57 community parameters of two dominant arthropod groups and vegetation in alluvial meadows.

58 Sampling took place in 2013, using suction samplers for arthropods and phytosociological relevés

59 for vegetation, in 83 meadows distributed along $200 \mathrm{~km}$ of the Loire Valley (France). Pair-matched

60 approach (by R-ANOVA) was used to assess overall effects of AES whereas a gradient analysis

61 (GLM) was carried out to assess the impact of AES prescriptions (fertilisation and cutting-date)

62 together with indirect (long-term) and direct (short-term) effects of flooding.

63 No significant effect of AES was found on arthropod and plant assemblages,

64 abundance/productivity or diversity (both $\alpha$ and $\beta$ ), but the number of rare plant species was higher

65 in sites under AES. Prescriptions had little impact on most response variables considered; the only

66 significant impact being the positive effect of high-amounts of fertilisers on spider $\alpha$ - and $\beta$ -

67 diversities. Conversely, systematic long-term effects of flooding were found on all response

68 variables of spiders, carabids and plants, underlining the key role of this factor in alluvial meadows.

69 Our study demonstrates that maintaining or enhancing hydrological functioning of ecosystems is

70 even more important than regulating both the cutting-dates and the low input of fertilisers for

71 conservation purposes in flooded, already naturally nutrient rich, meadows.

73 Keywords: Coleoptera Carabidae, Araneae, stochastic disturbance, cutting-date, fertilizers. 


\section{Introduction}

75 Over the last decades, agricultural intensification has accelerated adverse effects on wildlife

76 (Millennium Ecosystem Assessment 2005). In Europe, agri-environment schemes (AES) have been

77 implemented to counteract these effects by providing financial incentive for farmers to adopt

78 extensive agricultural practices. Farmers involved in AES preferentially engage fields which are

79 less suitable for intensive farming (Kleijn \& van Zuijlen, 2004), explaining why semi-natural

80 grasslands are especially targeted by AES.

81 Investments in AES were substantial, with for example 34.9 billion Euros provided for 2007-2013

82 programmes (COM, 2008). They currently cover $21 \%$ of all farmlands in the 27 EU countries.

83 Despite these high financial inputs, AES seem to have contrasting successes (Kleijn et al., 2006),

84 depending on the AES type and the model studied. For example, AES are recognised to have

85 positive effects on birds in the UK (Brereton, Warren, Roy, \& Stewart, 2007) and on pollinators in

86 Switzerland (Albrecht, Duelli, Muller, Kleijn, \& Schmid, 2007). However, AES also prove

87 damaging when poorly designed or when targeting single taxon (Konvicka et al., 2007). Results on

88 plant diversity are usually reported to be positive (e.g., Kleijn, Berendse, Smit, \& Gilissen, 2001;

89 Critchley, Walker, Pywell, \& Stevenson, 2007). Monitoring and evaluating these schemes is

90 imperative to improve their efficiency and maximize the conservation outcomes.

91 Evaluation of AES impact has usually focused on birds (Kleijn, Berendse, Smit, \& Gilissen, 2001,

92 Kleijn et al., 2006; Marshall, West, \& Kleijn, 2006) and vegetation (Critchley, Walker, Pywell, \&

93 Stevenson, 2007) mainly because they are the main targets of AES as arthropods are often neglected

94 in biodiversity conservation policies (e.g., Cardoso, Erwin, Borges, \& New, 2011). Nevertheless,

95 some studies also dealt with arthropods- mainly bees and grasshoppers (Kleijn, Berendse, Smit, \&

96 Gilissen, 2001; Knop, Kleijn, Herzog, \& Schmid, 2005), and found positive effects of AES. Despite 
97 their recognised indicator value in agricultural landscapes, predator arthropods like spiders and

98 carabid beetles remain relatively less studied in the context of AES compared to other taxa.

99 Flooding is a key driver of intertidal and riparian ecosystems, and particularly of arthropod

100 communities (Desender \& Maelfait, 1999) and vegetation (Violle et al., 2011). Arthropod

101 communities of European rivers are likely to use a 'risk strategy' to survive in this naturally

102 disturbed habitat. The strategy consists of a suite of life history traits such as high productivity ('r-

103 strategy'), high capacity for dispersion, and active recolonisation from areas that have been

104 sheltered from flooding (Zulka, 1994). Vertical emigration to uplands or higher vegetation is also

105 expected to increase recolonisation success (Adis \& Junk, 2002). A few terrestrial species also

106 withstand short to prolonged (up to several weeks) periods of submersion (e.g., insects: Hoback \&

107 Stanley, 2001, spiders: Pétillon et al., 2009). Conversely, flood events can be seen as a way to

108 colonise new habitats and exchange individuals between distant populations (Lambeets et al.,

109 2010), possibly enhancing among-site diversity in the long term. In the short-term, flood events

110 strongly reduce local diversity. Floodplains are generally characterized by a low percentage of

111 stenotopic species (Lafage, Papin, Secondi, Canard, \& Pétillon, 2015). Specialist species with

112 adaptations to flooding are found in more regularly flooded habitats like gravel banks (Lambeets,

113 Vandegehuchte, Maelfait, \& Bonte, 2008) or salt marshes (Pétillon, Potier, Carpentier \& Garbutt,

114 2014).

115 No study has assessed the relative effects of AES vs. stochastic disturbances induced by flooding in

116 such ecosystems, yet their expected effects on biodiversity are potentially opposite. Consequently,

117 no or few effects of AES in shaping arthropod and plant assemblages are expected in floodplains.

118 To test this hypothesis, we evaluated the role of AES and flooding in explaining $\alpha$ and $\beta$ diversities,

119 abundances (biomass for plants), species rarity and assemblage composition of two non-target

120 groups (spiders and carabids) and vegetation in the flooded meadows of the Loire River (France).

121 For spiders and carabids, analyses of rarity were not performed because of the lack of proper 
122 national or regional statuses of rarity (the English classification cannot be applied here: Pétillon,

123 Courtial, Canard, \& Ysnel, 2007), and also because the number of stenotopic and/or rare species is

124 low in these habitats (Lafage, Papin, Secondi, Canard, \& Pétillon, 2015).

\section{Material and methods}

\section{Study area and sampling design}

128 The study area covered $200 \mathrm{~km}$ of the Loire Valley (France: Fig. 1). Land is mainly covered by hay

129 meadows with an extensive hedgerow network. Meadows are usually cut in early or mid-summer

130 with second-crop grazing. The amount of fertilisers is generally low as regular winter and spring

131 floods bring a large amount of organic matter into the system. Pesticides are seldom used. Thus, the

132 management intensity is rather low. The study site included four AES zones with various

133 prescriptions regarding cutting-dates and fertilizers. Cutting-dates were between June 5th to July

134 20th, within four defined classes: free (not under AES), before June 20th, between June 20th and

135 July 1 st, after July 1 st. Fertiliser prescriptions were 0,30 or $60 \mathrm{~N}$ unit/ha. A 'free' class was added

136 for sites not under AES. Almost all meadows are flooded during winter for about 3 months, but in

1372012 and 2013, the study sites were also flooded during spring for 5 to 22 days. Spring-flood had 138 not occurred since 2004 in the Loire Valley.

139 Carabids, spiders and plants were sampled in 83 hay meadows. To reduce the variance between

140 fields, a paired-matched approach was used to test the impact of AES (see statistical analysis

141 section). Paired sites (with and without AES contract) were chosen with same vegetation types and

142 flooding regime. Distance between sites belonging to a pair was inferior to $1 \mathrm{~km}$. Table 1

143 summarizes the number of sites per treatment and moisture level. Site size ranged from 1.3 ha to

144265.3 ha $($ mean $=34.7 \pm 50.3 \mathrm{SD}$ ha $)$. 
145 Carabids and spiders were sampled using suction sampling (a standard technique providing

146 quantitative data, i.e. abundance of individuals, on arthropods: Brook, Woodcock, Sinka, and

147 Vanbergen, 2008). Each site was sampled once during June 2015 before the first cutting date- given

148 the strong impact of cutting on spiders and carabids (e.g., Lafage \& Pétillon 2014). Suction

149 sampling was realised using a $12.5 \mathrm{~cm}$ diameter intake placed on the ground. At each sampling site,

1505 samples (10 x 15 s suctions) were taken (total area: $\left.0.12 \mathrm{~m}^{2} / \mathrm{sample}\right)$. Samples were stored in $70 \%$

151 alcohol and taken to the laboratory for sorting and identification to species level.

152 At each site, plants were sampled once during spring 2013 (from June $1^{\text {st }} 2013$ to July $10^{\text {th }} 2013$,

153 before the first cutting date). Sampling followed the Braun-Blanquet (1928) method. One

154 phytosociological relevé per sampling site was made in a $16 \mathrm{~m}^{2}$ plot. Vegetation biomass was

155 approximated using a vegetation index derived from MODIS satellite imagery: the Enhanced

156 Vegetation Index (EVI: Lafage, Secondi, Georges, Bouzillé, \& Pétillon, 2014) measured during 16

157 days by LP DAAC (product MOD13Q1).

\section{Statistical analysis}

160 Spatial autocorrelation, tested using Moran's I, was low enough (see Appendix A, table 1) to be

161 neglected (Gerisch, Dziock, Schanowski, Ilg, \& Henle, 2012). Spatial patterns in response variables

162 were also researched using Moran's eigenvector maps (MEM) following Borcard, Gillet, and

163 Legendre (2011), but they were not significant (see Appendix A, table 2).

164 Arthropod $\alpha$-diversities were estimated for each sampling site using the average of four non-

165 parametric estimators based on species incidence: Chao1, Jacknife1, Jacknife2 and Bootstrap

166 (Carvalho et al. 2012). $\beta$-diversity was estimated through a dissimilarity matrix (corresponding to

167 Sørensen pair-wise dissimilarity) partitioned into its two components -species turnover ( $\beta \mathrm{t})$ and

168 nestedness ( $\beta$ n)- following Baselga (2010) and using the betapart R package (Baselga \& Orme 
169

170

171

172 A paired-sample approach (with or without AES) was used to test the overall AES effect on

2012). Vegetation diversity was estimated by the classical Shannon index. Plant rarity was estimated using the number of plants red-listed at either national or regional scale per sample. As no red list exists for spiders and carabids in France, analyses on arthropod rarity were not performed.

173 abundance/productivity, $\alpha$-diversity, $\beta$-diversity and rarity (plants) of arthropods and plants.

174 Repeated analyses of variance (R-ANOVA) with site as the within-subjects factor (e.g., Varet,

175 Burel, Lafage \& Pétillon, 2013) and AES presence/absence as a fixed factor were performed

176 between paired sites presenting similar abiotic conditions (see similar designs in previous studies on

177 AES efficiency: Knop, Kleijn, Herzog, \& Schmid, 2005; Kleijn et al. 2006; Scheper et al. 2013).

178 To test for differences in spider, carabid and plant assemblages between sites under AES and sites 179 not under AES, analyses of variance (ANOSIM) were performed.

180 To test for differences in $\beta$-diversities among groups (i.e., between sites under AES and not under 181 AES), multiple-site dissimilarity matrices were computed using the betapart package for R (Baselga $182 \&$ Orme 2012) and the Simpson dissimilarity index. We then performed a re-sampling procedure in the $\beta$-diversity matrix ( 50 pairs of sites were randomly sampled 50 times) to perform multiple comparison tests.

185 To investigate arthropod and plant responses to management and flooding, drivers of species assemblages were investigated using constrained analysis. The choice between redundancy analysis

187 (RDA) and constrained correspondence analysis (CCA) was made according to the axis length of a detrended correspondence analysis (DCA). Abundances of all species (for arthropods) and BraunBlanquet coefficients of abundance (for plants) were the response variables. The cutting-date (four 190 classes), fertiliser input (three levels), a variable describing whether or not the site had been flooded 191 during spring 2013 (i.e., binary variable for short-term effects of flooding), and a moisture gradient 192 (i.e., discrete variable for long-term effects of flooding) were predictors. Five moisture classes were 
193 defined from low (1) to very high (5) according to the mean Ellenberg indicator value (Ellenberg et

194 al., 1992) of each vegetation type (defined by a Two-Way Indicator Species Analysis). Class 1

195 corresponded to sites with mean Ellenberg value lower the 5 (mean=4.6), class 2 to sites with

$1965<$ Ellenberg value $<6$ (mean=5.4), class 3 to sites with $6<$ Ellenberg value $<7$ (mean=6.4), class 4 to

197 sites with $7<$ Ellenberg value $<8$ (mean=7.5) and class 5 to sites with Ellenberg value higher than 8

198 (mean=8.3). Monte Carlo tests with 999 permutations were carried out to test the significance of

199 the selected environmental factors and constrained analyses axes.

200 Responses of arthropod and plant $\alpha$-diversities, and abundances and vegetation productivity to both

201 the cutting-date (four classes) and fertiliser input (three levels) were tested using Generalised Linear

202 Models (GLMs) with gaussian distribution and a stepwise model selection by AIC (Akaike, 1974).

203 Flooding (i.e., binary variable for short-term effects of flooding) and moisture (five classes)

204 variables were also included. As flooding was expected to influence both the effects of the cutting-

205 date and of fertiliser amounts, interactions between those variables were also included. The same

206 GLM were applied to explain plant rarity. Pairwise-t-test were relalised to compare means of

207 response variables depending on significant factors by GLM.

208 To identify the variables significantly influencing arthropod and plant $\beta$-diversities, similarity

209 matrices corresponding to species turnover were regressed against environmental variables using

210 the Canonical Analysis of Principal Coordinates (CAP) implemented in the vegan package for R

211 (Oksanen et al. 2013). The model included the same explanatory variables as previous GLMs.

213 Statistical analyses were performed using R software (R Development Core team 2013) with vegan

214 (Oksanen et al., 2013), MASS (Venables \& Ripley 2002) and PCNM packages (Legendre, Borcard,

215 Blanchet, \& Dray, 2013). 


\section{Results}

218 A total of 6,036 spiders belonging to 97 species (see Appendix A, Table 3 for a detailed list of 219 species), 383 carabids (see Appendix A, Table 4 for a detailed list of species) belonging to 43 220 species, and 150 plant species (see Appendix A, Table 5 for a detailed list of species), 3 of them 221 being red-listed, were sampled. Spider and carabid assemblages were dominated by small aerial 222 dispersers: $78 \%$ of spiders were Linyphiidae and $78 \%$ of carabids were small winged species. 223 Spider assemblages were dominated by six linyphiid species Tenuiphantes tenuis (29.4\% of 224 individuals), Meioneta rurestris (7.0\%), Erigone dentipalplis (4.8\%), Bathyphantes gracilis (4.8\%), 225 Oedothorax fuscus (4.4\%) and Meioneta mollis (4.2\%). Carabid assemblages were dominated by 226 two harpaline species (Acupalpus exiguus: 51.0\% and Syntomus obscuroguttatus: 15.4\%) and one 227 bembidiine species (Bembidion biguttatus: 7.8\%). Plant assemblages were more balanced with ten 228 species cumulatively covering $35 \%$, with a frequency ranging from $6.1 \%$ (Lolium perenne) to $2.3 \%$ 229 (Plantago lanceolata).

230 Spider $\beta$-diversity was 0.97 , corresponding to $\beta \mathrm{t}=0.95$ and $\beta \mathrm{n}=0.02$. Carabid $\beta$-diversity was 2310.95 , corresponding to $\beta \mathrm{t}=0.92$ and $\beta \mathrm{n}=0.03$. Plant $\beta$-diversity was 0.96 , corresponding to $\beta \mathrm{t}=$ $2320.95 \beta \mathrm{n}=0.01 . \beta \mathrm{n}$ of the three groups was thus considered negligible and was not included in 233 further analyses.

234 Repeated ANOVAs revealed no significant effect of AES, site, or of the interaction between AES 235 and site on estimated $\alpha$-diversity and abundance of spiders and carabids, or on plant productivity 236 and $\alpha$-diversity (Table 2). A significant difference was found for plant rarity (Table 2), the number 237 of rare plants being higher in sites under AES. No significant difference was found between 238 assemblages of sites under AES vs. sites not under AES for spiders ( $\mathrm{R}=0.011, P=0.365)$, carabids $239(\mathrm{R}=0.008, P=0,347)$ or plants $(\mathrm{R}=-0.039, P=0,879)$. No significant difference was found between $\beta$ - 
240 diversity of sites under vs. not under AES for spiders $\left(\chi^{2}=49, P=0.473\right)$, carabids $\left(\chi^{2}=45.60\right.$,

$241 P=0.555)$ or plants $\left(\chi^{2}=46.74, P=0.625\right)$.

242 CCA on spider assemblages was significant $(\mathrm{F}=1.61, P=0.048)$ and explained $55.5 \%$ of the total

243 variance, with the first three axes of the CCA being significant (respectively $P=0.005 ; P=0.020$ and

$244 P=0.020$ ). Axis 1 and 3 were associated with moisture index and axis 2 with cutting date but the

245 only variable significantly explaining spider species composition was moisture $(\mathrm{F}=1.67, P=0.050)$

246 (Fig. 2).

247 RDA on carabid assemblages was not significant $(\mathrm{F}=0.98, P=0.430)$. RDA on plant assemblages 248 was significant $(\mathrm{F}=1.58, \mathrm{P}=0.005)$ and explained $66.3 \%$ of the total variance, with the first three 249 axes of the RDA being significant (respectively $P=0.005 ; P=0.015$ and $P=0.005$ ). Cutting-date, 250 occurrence of a spring flood in 2013 and moisture were the three variables significantly explaining 251 species assemblages (respectively $\mathrm{F}=1.99, P=0.010 ; \mathrm{F}=1.64, P=0.010 ; \mathrm{F}=2.89, P=0.010$ ).

252 In the GLMs performed on spider, carabid and plant $\alpha$ and $\beta$-diversities, abundance, and rarity, no 253 interaction between flooding and prescriptions (i.e., fertiliser amount and cutting-date) were found, 254 indicating that the impact of prescriptions, if any, was not influenced by flooding (Table 3).

255 Spider estimated $\alpha$-diversity was significantly influenced by fertiliser amount and moisture (Table 256 3). Sites under AES with $60 \mathrm{~kg} /$ ha nitrogen had higher estimated spider species richness (Fig. 3A).

257 Sites with low moisture level (classes 1 and 3, i.e. with less frequent floods) presented higher 258 estimated spider species richness than sites with very high moisture level (class 5) (Fig. 3B). Spider 259 abundance was significantly affected by fertilisation but post-hoc tests were not significant (Table 3 260 and Fig. 3C).

261 Spider $\beta$-diversity was significantly influenced by fertiliser amount and cutting-date (Table 3 and 262 Fig. 3D and 3E). Spider mean $\beta$-diversity increased with increasing fertiliser amount, with the 263 mean $\beta$-diversity being maximal with $60 \mathrm{~kg} / \mathrm{ha}$ and free fertilisation. An opposite response was 11 
264 found for the cutting-date: mean $\beta$-diversity was lower with later cutting dates and was maximal in

265 fields not under AES.

266 Carabid estimated $\alpha$-diversity was not influenced by predictive variables. Carabid abundance was

267 significantly influenced by moisture (Table 3), with higher carabid abundances in sites presenting

268 very high moisture level (class 5) (Fig. 3F).

269 Carabid $\beta$-diversity was significantly influenced by the occurrence of a flooding in spring 2013,

270 with the mean $\beta$-diversity being higher in fields that were not flooded during spring 2013 (Fig. 3G).

271 Plant $\alpha$-diversity was significantly influenced by moisture (Table 3). Plant $\alpha$-diversity of sites with a

272 high moisture level (Class 5) was significantly lower than those with a lower moisture level (class

273 1: Fig. 3H). Plant biomass (EVI) was significantly and positively impacted by moisture. Higher EVI

274 was found in moister sites, although differences among means were not significant. Fertiliser

275 amount, cutting-date, flooding, and moisture all had a significant effect on plant $\beta$-diversity (Table

276 3) but no significant effect of fertiliser amount and cutting-date were found when comparing mean

$277 \beta$-diversity between classes (Fig. 3I, 3J). Plant rarity was significantly impacted by moisture, with a

278 higher number of rare plants in moister sites (Table 3 and Fig. 3K).

\section{Discussion}

281 Overall, our results demonstrated no significant impact of AES on $\alpha$-diversity, $\beta$-diversity,

282 abundance / biomass and assemblages of the three groups studied in flooded meadows. A positive

283 effect was still found on rare plants. The absence of differences between meadows with vs.

284 meadows without AES is in accordance with some previous studies in non-flooded habitats that

285 focussed on spiders (Knop, Kleijn, Herzog, \& Schmid, 2005; Marshall, West, \& Kleijn, 2006),

286 carabids (Marshall, West, \& Kleijn, 2006) and plants (Kleijn, Berendse, Smit, \& Gilissen, 2001; 
287 Marshall, West, \& Kleijn, 2006). However, the existence of different levels in AES prescriptions

288 could potentially lower the impact of the most binding AES. Furthermore, meadows not under AES

289 remain rather extensively managed. It is thus possible that AES prescriptions do not constitute a

290 sufficient change in practices to have a detectable impact. The positive impact of AES

291 contractualisation on protected plants might not be a consequence of a change in farmers' practices.

292 Indeed, farmers preferentially engage in AES fields which are less suitable for intensive farming

293 (Kleijn \& van Zuijlen, 2004). In our case, fields with higher moisture levels are preferentially

294 engaged because soil bearing does not allow early cutting-dates. In the Loire Valley, most of the

295 protected plants are hygrophilous and are thus located in the engaged fields. In a large-scale study,

296 Kleijn et al. (2006) found no impact of AES on rare arthropods and plants, except for a positive one

297 on plant rarity in two countries. Our results are partly in opposition but, like in Kleijn et al. (2006),

298 the low number of rare species encountered prevents reliable estimates of AES impacts.

299 Spider assemblages and $\alpha$-diversity were significantly influenced by moisture which is in

300 accordance with Desender and Maelfait (1999), Pétillon, Georges, Canard, Lefeuvre, Bakker and

301 Ysnel (2008) and Lafage, Maugenest, Bouzillé, and Pétillon (2015). Cutting-date only influenced

302 spider $\beta$-diversity. Cutting-date has recently been shown to have little impact on spider $\alpha$-diversity

303 and abundance, but a significant impact on traits (Lafage \& Pétillon 2014), suggesting a potential

304 impact on $\beta$-diversity in accordance with our results.

305 We found spider $\beta$-diversity to decrease when cutting-dates were delayed. That could be explained

306 by the fact that the engaged farmers have to cut their fields in a very narrow time-frame in order to

307 maximise the nutritional value of hays (that decreases over time: Nocera, Parsons, Milton, \&

308 Fredeen, 2005). In fields not under AES, the diversity of cutting dates would oppositely increase the

$309 \beta$-diversity of spiders.

310 As opposed to the biodiversity-productivity theory (Grime, 1973), sites fertilised with $60 \mathrm{~kg} / \mathrm{ha}$

311 nitrogen supported highest spider $\alpha$-diversity. Sites not under AES were also not different from sites 
312 with medium or low nitrogen inputs. This is in accordance with studies suggesting a "bottom-up"

313 control of arthropod diversity (Siemann, 1998; Patrick, Fraser, \& Kershner, 2008) mediated by plant

314 and consumer biomass (Borer, Seabloom, \& Tilman, 2012). Nevertheless, these findings are still

315 being discussed as, for example, Haddad, Haarstad, and Tilman (2000) found insect diversity to be

316 negatively influenced by long-term fertiliser input. The lack of fertilisation effects on spider and

317 carabid abundances could be explained by a threshold effect. Fertiliser inputs remained low, even in

318 fields not under AES contract, compared to the large quantities of organic matter introduced in the

319 system by winter floods (Junk \& Wantzen, 2004). Consequently, the fertiliser levels might remain

320 too low to initiate a trophic cascade which is confirmed by the absence of impact of fertilisers on

321 plant biomass and $\alpha$-diversity (see below).

322 As expected, carabids were only influenced by spring floods and moisture, for $\beta$-diversity and

323 abundance respectively. Carabids have been shown to recover less rapidly than spiders after spring

324 floods (Lafage, Papin, Secondi, Canard, \& Pétillon, 2015), especially regarding species

325 composition, which could explain the impact of spring floods on carabid $\beta$-diversity. Gerisch et al.

326 (2012) demonstrated that carabid $\beta$-diversity remains high after important flooding events,

327 indicating persistent shifts in species assemblages. Gerisch et al. (2012) and Lafage, Papin,

328 Secondi, Canard, and Pétillon (2015) finally show massive decreases in carabid abundance after

329 spring floods. This dominance of small species could first be attributed to a sampling effect,

330 although suction sampling is usually recommended to quickly obtain a representative sample of

331 epigeic arthropod communities (e.g. Duffey 1974). In fact, Mommertz, Schauer, Kösters, Lang, and

332 Filser (1996) considered it an inefficient way to sample large arthropods (such as Carabidae and

333 Lycosidae). However, Brook, Woodcock, Sinka, and Vanbergen (2008) considered suction sampling

334 an efficient technique to sample arthropods, including Carabidae, pending a sufficient sampling

335 effort. Here we performed sampling duration and replication higher than recommanded by Brook,

336 Woodcock, Sinka, and Vanbergen (2008) for spiders (16x2s recommanded vs 5x10x15s performed) 
337 and slightly inferior than recommanded by Brook, Woodcock, Sinka, and Vanbergen (2008) for

338 beetles $(54,8 \times 15,6$ s recommended vs $5 \times 10 \times 15$ s performed) with similar sampling area. We can thus

339 consider that our results were not biased by the sampling technique, and that the dominance of

340 small aerial dispersers was a consequence of an environmental filter, here the stochasticity due to

341 flooding (Zulka 1994).

342 Plant $\alpha$-diversity, $\beta$-diversity, biomass and assemblages were systematically influenced by flooding

343 (i.e., moisture and occurrence of spring floods) because of both its large spatial extent (including

344 both AES and non-AES meadows) and its duration (here several months). These results are in

345 accordance with previous studies. The central role of moisture in shaping plant communities has

346 indeed been demonstrated by many authors (e.g., Dwire, Kauffman, Brookshire, \& Baham, 2004;

347 Wassen, Peeters, \& Olde Venterink, 2002; Zelnik \& Čarni, 2008). Moisture's role on plant diversity

348 has also been demonstrated. For example, Zelnik and Čarni (2008) found plant $\alpha$ and $\beta$-diversities

349 to be strongly and negatively influenced by moisture in wetlands. Plant rarity was also positively

350 affected by moisture, which is not surprising as most plant species protected in the area are

351 hygrophilous or meso-hydrophilous species.

352 Regarding AES prescriptions, cutting-date significantly influenced $\beta$-diversity and plant

353 assemblages. Late cutting dates are indeed well known to induce vegetation modifications by

354 favouring annual plant species; maximum plant $\alpha$-diversity being usually observed for late cutting-

355 dates (mid-June to mid-July) in European grasslands (e.g. Critchley, Walker, Pywell, \& Stevenson,

356 2007).

357 Fertilisation level had a significant impact only on plant $\beta$-diversity, which is in accordance with

358 Klimek et al. (2008) who found plant species $\beta$-diversity being influenced, at a local scale, by

359 fertilisation input. A significant reduction of $\alpha$-diversity and a biomass increase are usually observed

360 even for low levels of fertilizers (e.g., Plantureux, Peeters, \& Mccracken, 2005). Nevertheless, in

361 flooded grasslands, no effect of fertilisation on plant diversity was reported under $90 \mathrm{~kg} / \mathrm{ha} / \mathrm{yr}$ 
362 (Bonis, Dausse, Dia, \& Bouhnik-le Coz, 2008). Thus, the fertilisation level permitted in sites under

363 AES and effectively used in sites not under AES, may be too low to allow a detection of their

364 impact.

365 Our results suggest that flooding might be a stronger driver of vegetation and arthropod

366 assemblages than differences in cutting dates or low fertilizer inputs. The impact of flooding and

367 management practices seems to vary with organism mobility (Adis \& Junk, 2002). Indeed, we

368 found plants to be the organisms that are the most sensitive to perturbations induced by flooding,

369 and also to variations in management practices. Conversely, carabid assemblages, mainly composed

370 of highly mobile small species, were only influenced by flooding.

371 Our results further suggest that the regulation of cutting dates and low input fertilisers of grasslands

372 has few, if any, effects on arthropods and plants compared to those induced by a prolonged flooding.

373 Conservation actions in such ecosystems might have to focus on maintaining and/or enhancing

374 hydrological functioning in order to rewild those ecosystems (Merckx \& Pereira, 2014).

375 Nevertheless, because natural meadows are in constant regression by conversion to intensive

376 agriculture (Millennium Ecosystem Assessment 2005), AES can yet be considered an efficient way

377 of maintaining an endangered habitat, despite their limited efficiency in flooded systems.

\section{Acknowledgements}

382 We would like to thank the CORELA for its support, Charlotte Papin and Thomas Joubin for field

383 and laboratory assistance, Arnaud Horellou for his help in identifying problematic carabids, and

384 Aldyth Nys and Len Gambla for editing the English. Two anonymous referees provided very useful 
385 comments on earlier drafts. This study was funded by 'Plan Loire Grandeur Nature' (FEDER),

386 'Région Pays de la Loire' and 'Agence de l'Eau Loire-Bretagne'.

387

388 "Appendix A. Supplementary data

389 Supplementary data associated with this article can be found, in the online version, at XXXXX." 
391 Adis J., \& Junk, W. J. (2002). Terrestrial invertebrates inhabiting lowland river floodplains of 392 Central Amazonia and Central Europe: a review. Freshwater Biology 47, 711-731.

393 Akaike, H. (1974). A new look at the statistical model identification. IEEE Transactions on $394 \quad$ Automatic Control, 19, 716-723.

395

Albrecht, M., Duelli, P., Muller, C., Kleijn, D., \& Schmid, B. (2007). The Swiss agri-environment scheme enhances pollinator diversity and plant reproductive success in nearby intensively managed farmland. Journal of Applied Ecology, 44, 813-822.

Baselga, A. (2010). Partitioning the turnover and nestedness components of beta diversity. Global Ecology and Biogeography, 19, 134-143.

Baselga, A., \& Orme, C.D.L. (2012). betapart: an R package for the study of beta diversity. Methods in Ecology Evolution, 3, 808-812.

Bonis, A., Dausse, A., Dia, A., \& Bouhnik-le Coz, M. (2008). Fertilisation et qualité de l'eau en prairies naturelles humides (marais de l'Ouest). Fourage, 196, 485-489.

Borcard, D., Gillet, F., \& Legendre, P. (2011). Numerical ecology with R. Springer, New York.

Borer, E. T., Seabloom, E. W., \& Tilman, D. (2012). Plant diversity controls arthropod biomass and temporal stability. Ecology Letters, 15, 1457-1464. http://doi.org/10.1111/ele.12006

Braun-Blanquet, J. (1928). Pflanzensoziologie. Grundzüge der Vegetationskunde. Springer, Wien, AT.

Brereton, T. M., Warren, M. S., Roy, D. B., \& Stewart, K. (2007). The changing status of the Chalkhill Blue butterfly Polyommatus coridon in the UK: the impacts of conservation policies and environmental factors. Journal of Insect Conservation, 12, 629-638.

Brook, A. J., Woodcock, B. A., Sinka, M., \& Vanbergen, A.J. (2008). Experimental verification of suction sampler capture efficiency in grasslands of differing vegetation height and structure. Journal of Applied Ecology, 45, 1357-1363. 
415 Cardoso, P., Erwin, T. L., Borges, P. A. V., \& New, T. R. (2011). The seven impediments in

416 invertebrate conservation and how to overcome them. Biological Conservation, 144, 2647-

$417 \quad 2655$

418 Carvalho, J. C., Cardoso P., Crespo, L. C., Henriques, S., Carvalho, R., \& Gomes, P. (2012).

419 Determinants of spider species richness in coastal dunes along a gradient of mediterraneity.

Insect Conservation and Diversity, 5,127-137.

421 COM (2008). Rural development in the European Union: Statistical and economic information.

$422 \quad$ Brussels.

423 Critchley, C. N. R., Walker, K. J., Pywell, R. F., \& Stevenson, M. J. (2007). The contribution of 424 English agri-environment schemes to botanical diversity in arable field margins, in: Aspects of $425 \quad$ Applied Biology. pp. 293-300.

426 Desender, K., \& Maelfait, J. P. (1999). Diversity and conservation of terrestrial arthropods in tidal

Duffey, E. (1974). Comparative sampling methods for grassland spiders. Bulletin of the British 429 Arachnological Socity, 3, 34-37.

430 Dwire, K. A., Kauffman, J. B., Brookshire, E. N. J., \& Baham, J. E. (2004). Plant biomass and 431 species composition along an environmental gradient in montane riparian meadows.

432 Oecologia, 139, 309-17. http://doi.org/10.1007/s00442-004-1498-2

433 Ellenberg, H., Weber, H. E., Düll, R., Wirth, V., Werner, W., \& Paulißen, D. (1992). Zeigerwerte 434 von Pflanzen in Mitteleuropa, 2nd ed. Scripta Geobotanica, 18, 1-258.

435 Gerisch, M., Dziock, F., Schanowski, A., Ilg, C., \& Henle, K. (2012). Community resilience 436 following extreme disturbances: the response of ground beetles to a severe summer flood in a 437 central European lowland stream. River Research and Applications, 28, 81-92.

438 Grime, J. P. (1973). Control of species density in herbaceous vegetation. Journal of Environmental 439 Management, 1, 151-167. 
Hoback, W. W., \& Stanley D. W. (2001). Insects in hypoxia. Journal of Insect Physiology 47, 533542.

Junk, W. J., \& Wantzen, M. (2004). The flood pulse concept: new aspects, approaches and applications - an update. In Second International Symposium on the Management of Large Rivers for Fisheries (pp. 117-140). Food and Agriculture Organization and Mekong River Commission, FAO Regional Office for Asia and the Pacific.

Kleijn, D., Baquero, R. A., Clough, Y., Díaz, M., De Esteban, J., Fernández, F., Gabriel, D., Herzog, F., Holzschuh, A., Jöhl, R., Knop, E., Kruess, A., Marshall, E. J. P., Steffan-Dewenter, I., Tscharntke, T., Verhulst, J., West, T. M., \& Yela, J. L. (2006). Mixed biodiversity benefits of agri-environment schemes in five European countries. Ecological Letters, 9, 243-54; discussion 254-7.

Kleijn, D., Berendse, F., Smit, R., \& Gilissen, N. (2001). Agri-environment schemes do not effectively protect biodiversity in Dutch agricultural landscapes. Nature, 413, 723-725.

Kleijn, D., \& van Zuijlen, G. J. C. (2004). The conservation effects of meadow bird agreements on farmland in Zeeland, the Netherlands, in the period 1989-1995. Biological Conservation, 117, $443-45$.

Klimek, S., Marini, L., Hofmann, M., \& Isselstein, J. (2008). Additive partitioning of plant diversity with respect to grassland management regime, fertilisation and abiotic factors. Basic and Applied Ecology, 9, 626-634.

Knop, E., Kleijn, D., Herzog, F., \& Schmid, B. (2005). Effectiveness of the Swiss agri-environment scheme in promoting biodiversity. Journal of Applied Ecology, 43, 120-127.

Konvicka, M., Benes, J., Cizek, O., Kopecek, F., Konvicka, O., \& Vitaz, L. (2007). How too much care kills species: Grassland reserves, agri-environmental schemes and extinction of Colias myrmidone (Lepidoptera: Pieridae) from its former stronghold. Journal of Insect Conservation, $12,519-525$.

Lafage, D., \& Pétillon, J. (2014). Impact of cutting date on carabids and spiders in a wet meadow. Agriculture, Ecosystems \& Environment, 185, 1-8. 
Lafage, D., Maugenest, S., Bouzillé, J.-B., \& Pétillon, J. (2015). Disentangling the influence of local and landscape factors on alpha and beta diversities: opposite response of plants and ground-dwelling arthropods in wet meadows. Ecological Research, 30, 1025-1035.

Lafage, D., Papin, C., Secondi, J., Canard, A., \& Pétillon, J. (2015). Short term recolonisation by arthropod after a spring flood, with a focus on spiders and carabids. Ecohydrology, 8, 15841599. doi: $10.1002 /$ eco. 1606

Lafage, D., Secondi, J., Georges, A., Bouzillé, J.-B., \& Pétillon, J. (2014). Satellite-derived vegetation indices as surrogate of species richness and abundance of ground beetles in temperate floodplains. Insect Conservation and Diversity, 7, 327-333.

Lambeets, K., Breyne, P., \& Bonte, D. (2010). Spatial genetic variation of a riparian wolf spider Pardosa agricola (Thorell, 1856) on lowland river banks: The importance of functional connectivity in linear spatial systems. Biological Conservation, 143, 660-668.

Lambeets, K., Vandegehuchte, M. L., Maelfait, J.-P., \& Bonte, D. (2008). Understanding the impact of flooding on trait-displacements and shifts in assemblage structure of predatory arthropods on river banks. Journal of Animal Ecology, 77, 1162-74. doi:10.1111/j.13652656.2008.01443.x

Legendre, P., Borcard, D., Blanchet, F. G., \& Dray, S. (2013). PCNM: MEM spatial eigenfunction and principal coordinate analyses.

Marshall, E. J. P., West, T. M., \& Kleijn, D. (2006). Impacts of an agri-environment field margin prescription on the flora and fauna of arable farmland in different landscapes. Agriculture, Ecosystems \& Environment, 113, 36-44.

Merckx, T., \& Pereira, H. M. (2014). Reshaping agri-environmental subsidies: From marginal farming to large-scale rewilging. Basic and Applied Ecology, 16, 95-103.

Millennium Ecosystem Assessment (2005). Ecosystems and Human Well-Being: Biodiversity Synthesis. Washington DC. 
492 Mommertz, S., Schauer, C., Kösters, N., Lang, A., \& Filser, J. (1996). A comparison of D-Vac

493 suction, fenced and unfenced pitfall trap sampling of epigeal arthropods in agro- ecosystems.

$494 \quad$ Annales Zoologici Fennici, 33, 117-124.

495 Nocera, J. J., Parsons, G. J., Milton, G. R., \& Fredeen, A. H. (2005). Compatibility of delayed 496 cutting regime with bird breeding and hay nutritional quality. Agriculture, Ecosystems \& 497 Environment, 107(2-3), 245-253. doi:10.1016/j.agee.2004.11.001

498 Oksanen, J., Blanchet, F. G., Kindt, R., Legendre, P., Minchin, P. R., O’Hara, R. B., Simpson, G. L., 499 Solymos, P., Henry, M. H., Wagner, S., \& Wagner H. (2013). vegan: Community Ecology $500 \quad$ Package.

501 Patrick, L. B., Fraser, L. H., \& Kershner, M. W. (2008). “Brown” World Invertebrates Contradict 502 “Green” World Biodiversity Theory. Research Letters in Ecology, 2008, 1-4.

Pétillon, J., Courtial, C., Canard, A., \& Ysnel, F. (2007). First assessment of spider rarity in Western France. Revista Ibérica de Arachnologia, 15, 106-113.

Pétillon J., Georges A., Canard A., Lefeuvre J.-C., Bakker J. P., \& Ysnel, F. (2008) Influence of abiotic factors on spider and ground beetles communities in different salt-marsh systems. Basic and Applied Ecology, 9, 743-751.

Pétillon, J., Montaigne, W., \& David, R. (2009). Hypoxic coma as a strategy to survive inundation in a salt-marsh inhabiting spider. Biology Letters, 5, 442-445.

Pétillon J., Potier, S., Carpentier, A., \& Garbutt, A. (2014). Evaluating the success of managed realignment for the restoration of salt marshes: lessons from invertebrate communities.

513 Plantureux, S., Peeters, A., \& Mccracken, D. (2005). Biodiversity in intensive grasslands: Effect of management, improvement and challenges. Agronomy Research, 3, 153-164.

515 R Development Core team (2013) R: A Language and Environment for Statistical Computing. 
516 Scheper, J., Holzschuh, A., Kuussaari, M., Potts, S. G., Rundlöf, M., Smith, H. G., \& Kleijn, D.

517 (2013). Environmental factors driving the effectiveness of European agri-environmental

518 measures in mitigating pollinator loss - a meta-analysis. Ecology Letters, 16, 912-920.

519 Siemann, E. (1998). Experimental tests of effects of plant productivity and diversity on grassland $520 \quad$ arthropod diversity. Ecology, 79, 2057-2070

521 Varet, M., Burel, F., Lafage, D., \& Pétillon, J. (2013). Age-dependent colonisation of urban

522 habitats : a diachronic approach using carabid beetles and spiders. Animal Biology, 63, 257523269.

524 Venables, W. N., \& Ripley, B. D. (2002). Modern Applied Statistics with S, Fourth. ed. Springer, $525 \quad$ New York.

526 Violle, C., Bonis, A., Plantegenest, M., Cudennec, C., Damgaard, C., Marion, B., Le Cœur, D., \& 527 Bouzillé, J.-B. (2011) Plant functional traits capture species richness variations along a 528 flooding gradient. Oikos, 120, 389-398.

529 Wassen, M. J., Peeters, W. H. M., \& Olde Venterink, H. (2002). Patterns in vegetation, hydrology 530 and nutrient availability in an undisturbed river floodplain in Poland. Plant Ecology, 165, 2753143.

532 Zelnik, I., \& Čarni, A. (2008). Distribution of plant communities, ecological strategy types and 533 diversity along a moisture gradient. Community Ecology, 9, 1-9.

$534 \quad$ http://doi.org/10.1556/ComEc.9.2008.1.1

535 Zulka, K. P. (1994). Carabids in a Central Europe floodplain: species distribution and survival 536 during inundations. In K. Desender et al. (Ed.), Carabid Beetles: Ecology and Evolution. $537 \quad$ Kluwer Academic Publishers, Netherlands. 
542 Fig. 1. Location of the study sites in the Loire watershed (France). Grey surfaces indicate meadows

543 and black dots correspond to the sampled meadows.

544 Fig. 2. CCA on spider species. Sites under AES are represented by triangles and sites not under

545 AES by circles. Only species most contributing to axes are represented. ( CHEPEN:

546 Cheiracanthium pennyi, CRUSTI: Crustulina sticta, DIPLAT: Diplocephalus latifrons, DRALAP:

547 Drassodes lapidosus, ENOOVA: Enoplognatha ovata, EUOFRO: Euophrys frontalis, EUOHER:

548 Euophrys herbigrada, EVAARC: Evarcha arcuata, ERIVAG: Erigone vagans, HAPSIG:

549 Haplodrassus signifer, HYPPYG: Hypsosinga pygmaea, LARCOR: Larinioides cornutus,

550 LEPZYM: Leptyphantes zimmermanni, MEIBEA: Meioneta beata, MEISIM: Meioneta

551 simplicitarsis, METPRO: Metopobactrus prominulus, NEOSUA: Neottiura suaveolens, OEDAGR:

552 Oedothorax agrestis, OZYRAU: Ozyptila rauda, OZYTRU: Ozyptila trux, PARAGR: Pardosa

553 agrestis, PARPAL: Pardosa palustris, PISMIR: Pisaura mirabilis, PORMIC: Porrhomma

554 microphtalmum, PORPYG: Porrhomma pygmaeum, SAVFRO: Savignia frontata, SILELE:

555 Silometopus elegans, STEPHA: Steatoda phalerata, THASTRE: Thanatus striatus, THEBIM:

556 Theridion bimaculatum, THEIMP: Theridion impressum, TIBOBL: Tibelus oblongus, TRISAX:

557 Trichoncus saxicola, TROSPI: Trochosa spinipalpis, XERNEM: Xerolycosa nemoralis, XYSERR:

558 Xysticus erraticus, ZELCIV: Zelotes civicus, ZORPAR: Zora parallela.

560 Fig. 3. Variations in mean response variables depending on significant factors by GLM (different

561 successive letters indicate significant differences in means according to Tukey's post-hoc tests with

562 Bonferroni correction). (A) Mean estimated spider richness by fertiliser class (Free: not under

563 AES). (B) Mean estimated spider richness by moisture gradient (1 to 5: increasing moisture

564 gradient). (C) Spider abundance per $0.12 \mathrm{~m}^{2}$ by fertiliser class. (D): Spider mean $\beta$-diversity by 
565 fertiliser class. (E) Spider mean $\beta$-diversity by cutting date (Free: not under AES, CD1: before 20th

566 June, CD2: between 20th June and 1st July, CD3: after 1st July). (F) Carabid abundance by

567 moisture gradient. (G) Carabid mean $\beta$-diversity by flooding (Yes: sites flooded during summer

568 2013, No: sites not flooded). (H) Plant Shannon Index by moisture gradient. (I) Plant mean $\beta$ -

569 diversity by flooding. (J) Plant mean $\beta$-diversity by moisture gradient. (K) Number of rare plant

570 species by moisture gradient. The horizontal bar in box-plots indicates the median, the ends of the

571 boxes indicate the interquartile range, and the whiskers indicate the 10th and 90th quantiles. 

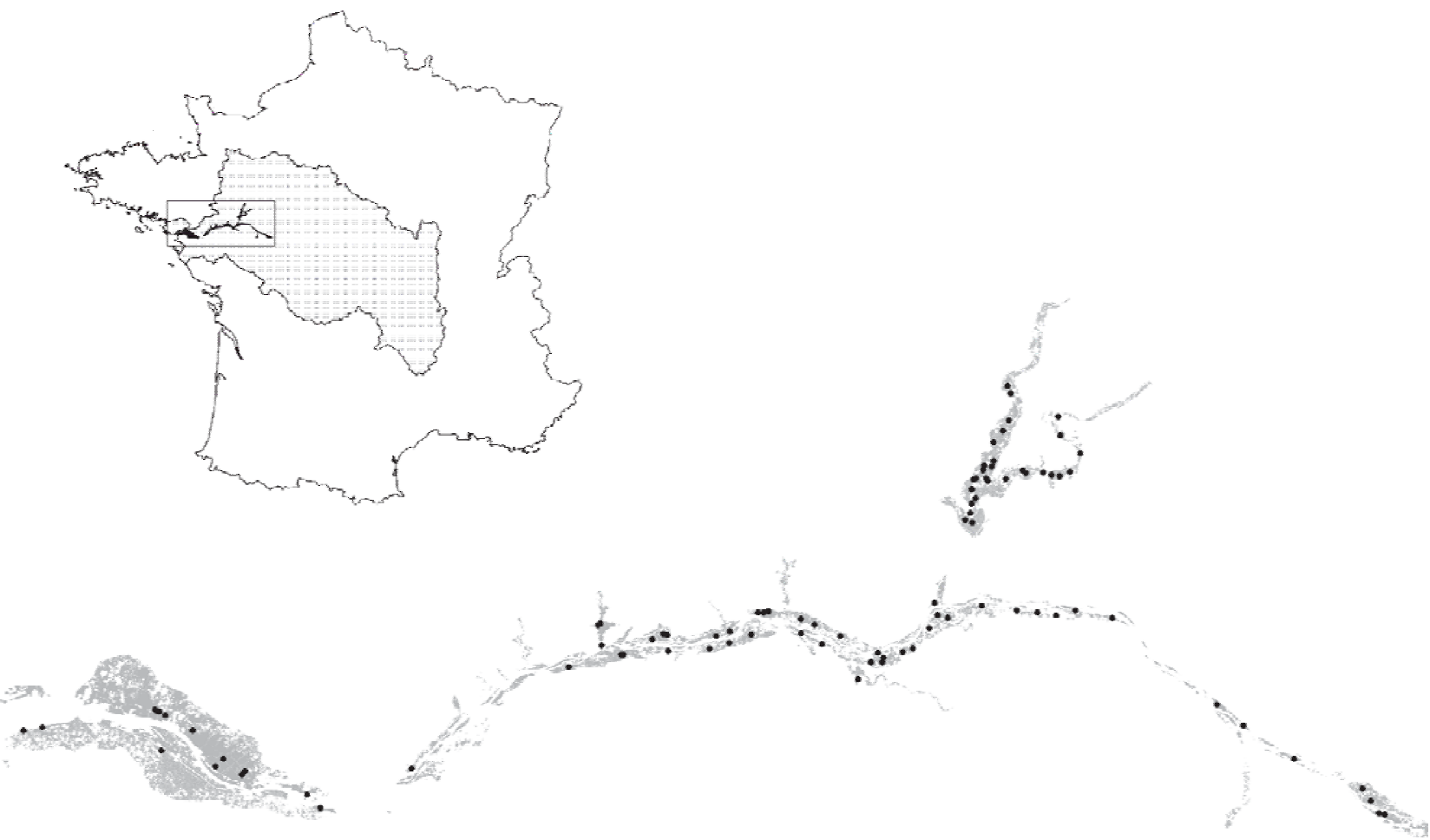

$\begin{array}{lll}0 & 10 & 20\end{array} \quad 30 \mathrm{~km}$

573 Figure 1. Lafage and Pétillon, 2015

574

575 


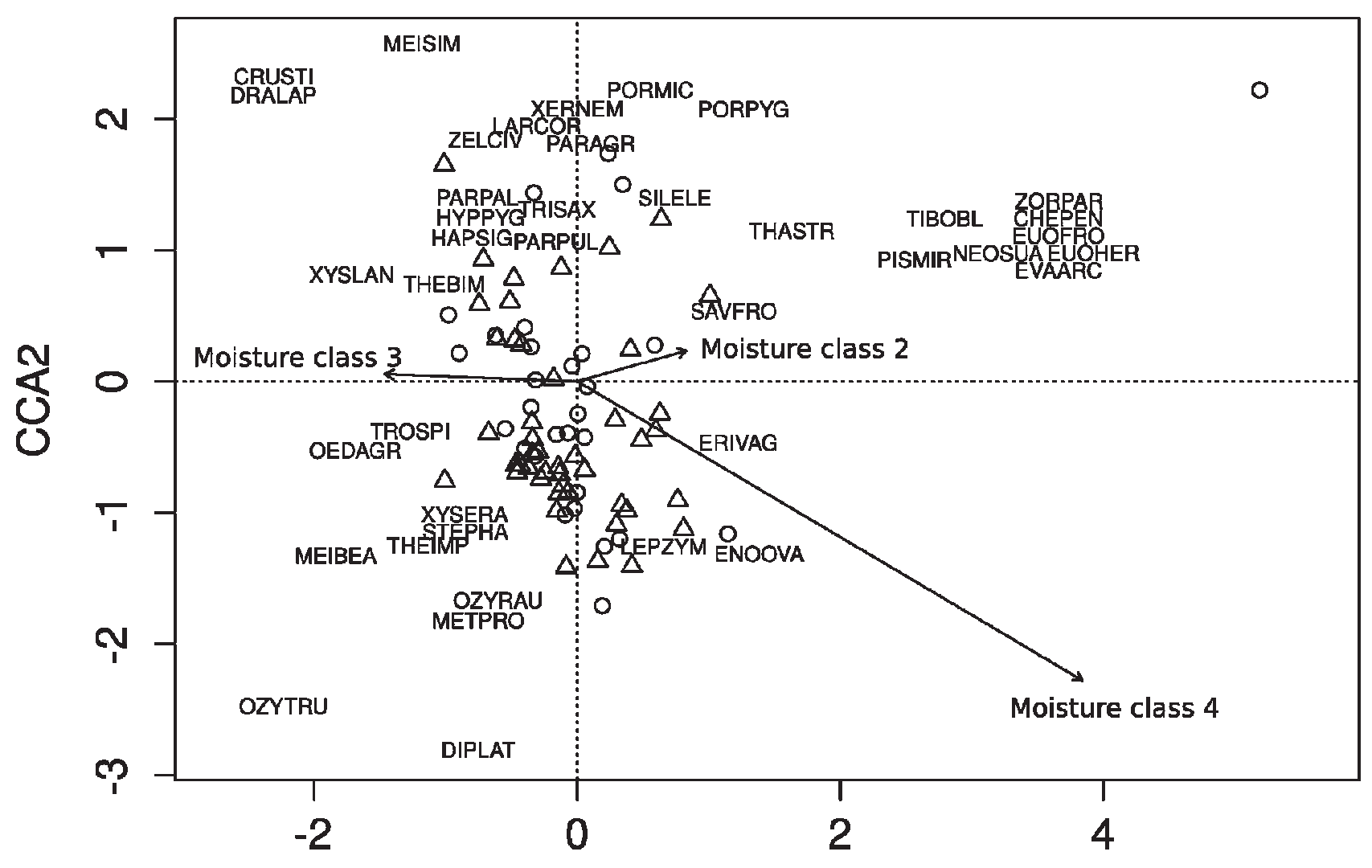

576 Figure 2 : Lafage and Pétillion, 2015

\section{CCA1}


(A) Spider mean richness

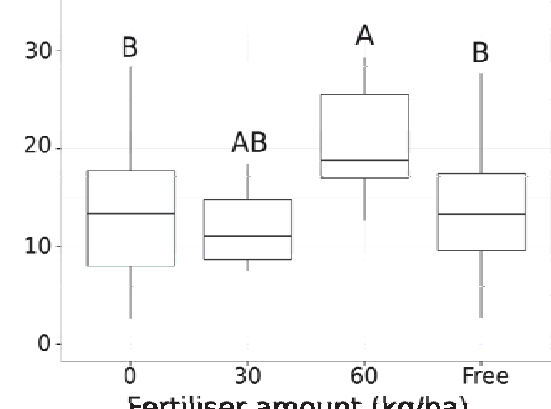
Fertiliser amount $(\mathrm{kg} / \mathrm{ha})$

(D) Spider $\beta$-diversity

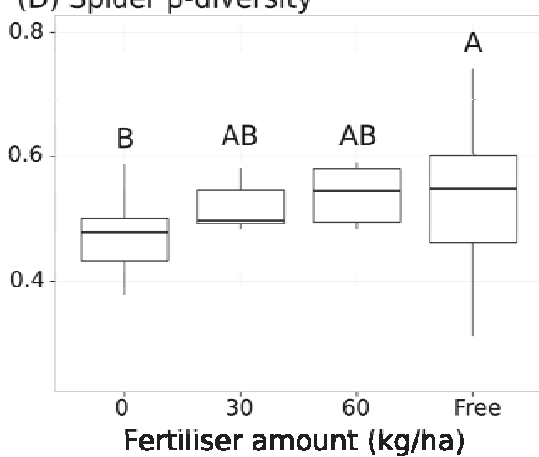

(G) Carabid $\beta$-diversity

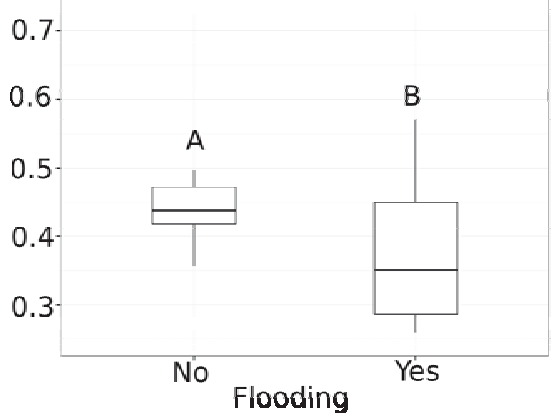

(j) Plant $\beta$-diversity

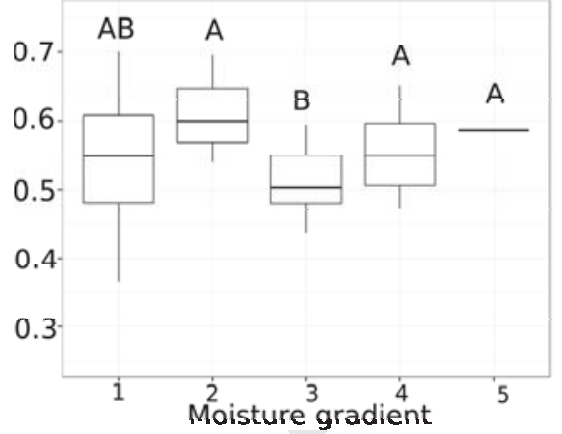

578 Figure 3 : Lafage and Pétillon, 2015
(B) Spider mean richness

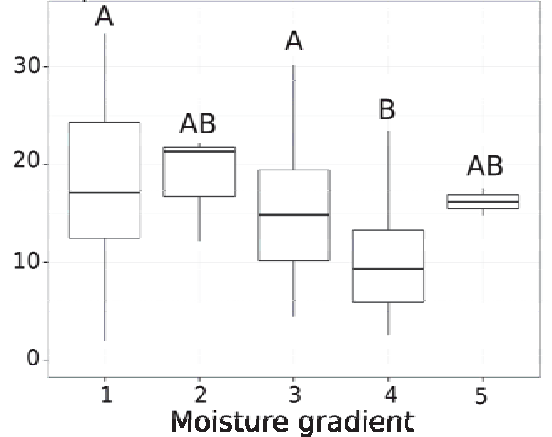

(E) Spider $\beta$-diversity

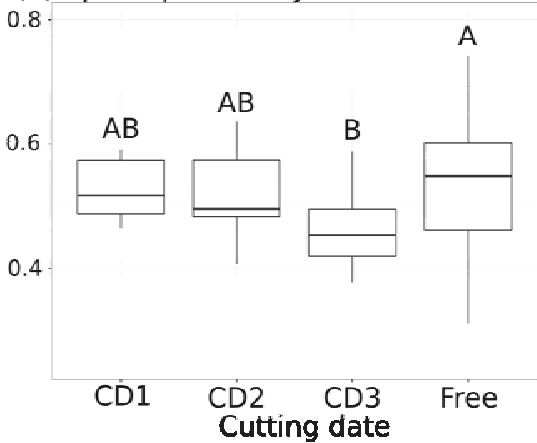

(H) Plant Shannon Index

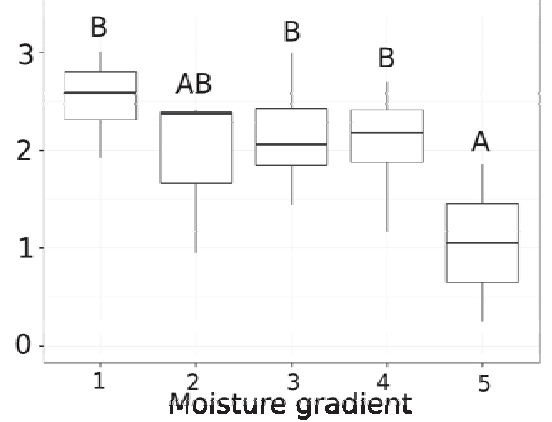

(K) \# rare plant species

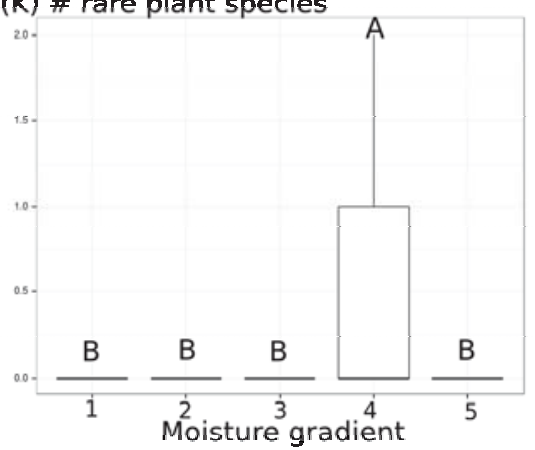

(C) Spider abundance $/ 0.12 \mathrm{~m}^{2}$ 3 .

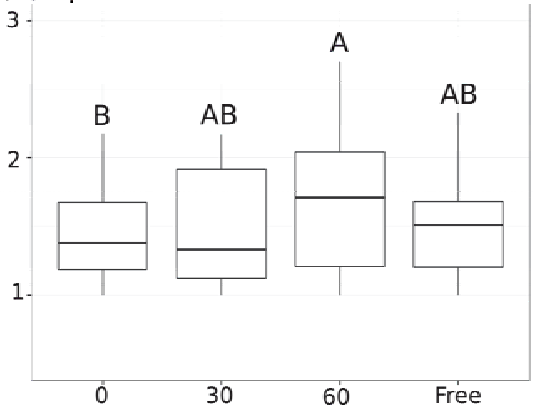

Fertiliser amount ( $\mathrm{kg} / \mathrm{ha})$

(F) Carabid abundance $/ 0.12 \mathrm{~m}^{2}$

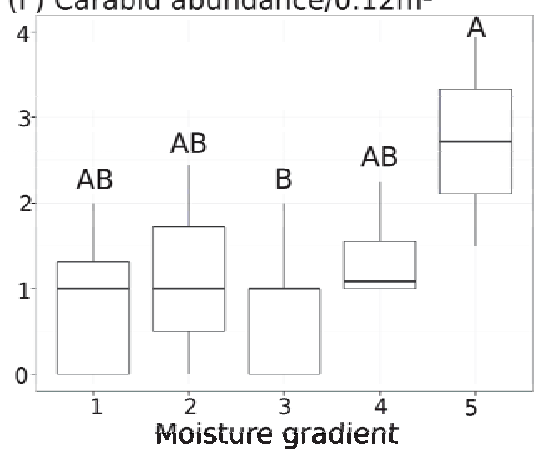

(I) Plant $\beta$-diversity

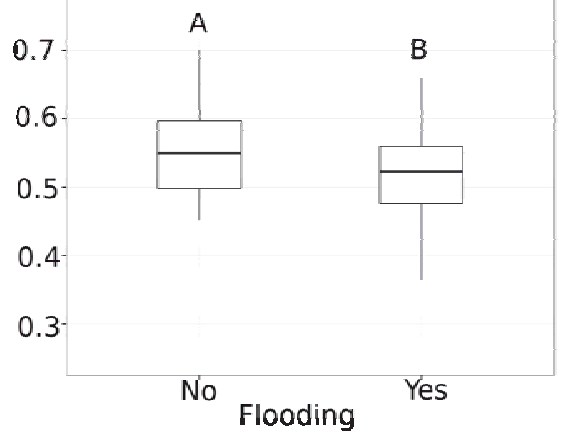


580 Table 1. Number of sites per class. Contract : whether or not sites are under AES contract;

581 Fertilisers : classes of fertiliser input alowed in $\mathrm{kg} / \mathrm{Ha}$; Cutting date : classes of cutting dates (Free:

582 not under AES, CD1: before 20th June, CD2: between 20th June and CD3: 1st July, after 1st July.);

583 Flooding: whether or not site has been flooded during summer 2013; Moisture: classes of Ellenberg

584 inidicator value for moisture from low (1) to very high (5).

\begin{tabular}{|c|c|c|}
\hline & classe & \#sites \\
\hline \multirow[t]{2}{*}{ Contract } & Yes & 42 \\
\hline & No & 41 \\
\hline \multirow[t]{4}{*}{ Fertilisers } & 0 & 15 \\
\hline & 30 & 17 \\
\hline & 60 & 10 \\
\hline & Free & 41 \\
\hline \multirow[t]{4}{*}{ Cutiing date } & CD1 & 12 \\
\hline & $\mathrm{CD} 2$ & 14 \\
\hline & CD3 & 16 \\
\hline & Free & 41 \\
\hline \multirow[t]{2}{*}{ Flooding } & No & 33 \\
\hline & Yes & 50 \\
\hline \multirow[t]{5}{*}{ Moisture } & 1 & 16 \\
\hline & 2 & 15 \\
\hline & 3 & 28 \\
\hline & 4 & 27 \\
\hline & 5 & 6 \\
\hline
\end{tabular}


589 Table 2. Per site means \pm s.e. of response variables for fields under AES or not (Free), with F and P

590 values for fixed factor (contract), within-subject factor (site) and their interaction (R-ANOVA).

591 Abundance: total number of individuals per $0.12 \mathrm{~m}^{2}$. Estimated species richness: average of four

592 non-parametric estimators based on species incidence: Chao1, Jacknife1, Jacknife2 and Bootstrap.

593

594

595

\begin{tabular}{|c|c|c|c|c|c|c|c|c|c|}
\hline & AES & \multirow[t]{2}{*}{ Free } & \multicolumn{2}{|c|}{ Contract } & \multicolumn{2}{|c|}{ Site } & \multicolumn{2}{|c|}{ Interaction } \\
\hline & & Mean \pm s.e. & & $\mathrm{F}$ & $\mathrm{P}$ & $\mathrm{F}$ & $\mathrm{P}$ & $\mathrm{F}$ & $\mathrm{P}$ \\
\hline \multirow[t]{2}{*}{ Spiders } & Abundance & $2.24 \pm 1.84$ & $1.83 \pm 1.19$ & 0.96 & 0.338 & 2.12 & 0.158 & 0.04 & 0.838 \\
\hline & $\begin{array}{l}\text { Esimated species } \\
\text { richness }\end{array}$ & $14.74 \pm 7.14$ & $10.50 \pm 3.97$ & 3.98 & 0.060 & 0.24 & 0.630 & 0.143 & 0.709 \\
\hline \multirow[t]{2}{*}{ Carabids } & Abundance & $1.02 \pm 1.01$ & $1.64 \pm 1.47$ & 1.53 & 0.228 & 0.06 & 0.804 & 0.05 & 0.833 \\
\hline & $\begin{array}{l}\text { Esimated species } \\
\text { richness }\end{array}$ & $2.08 \pm 2.40$ & $3.45 \pm 3.46$ & 1.13 & 0.298 & 2.47 & 0.129 & 0.10 & 0.760 \\
\hline \multirow[t]{4}{*}{ Plants } & Shannon Index & $2.15 \pm 0.42$ & $2.24 \pm 0.37$ & 0.19 & 0.667 & 2.08 & 0.162 & 0.02 & 0.883 \\
\hline & EVI & $5366 \pm 1187$ & $5135 \pm 1097$ & 0.31 & 0.594 & 0.29 & 0.594 & 1.43 & 0.243 \\
\hline & & & & 7.9 & 0.00 & 1.8 & 0.18 & 0.68 & 0.41 \\
\hline & Rarity & $4.73 \pm 2.81$ & $2.06 \pm 1.98$ & 9 & 9 & 7 & 4 & 3 & 7 \\
\hline
\end{tabular}

596

597

598

599

600 
603 Table 3. GLM selected by stepwise procedure for spider, carabid and plant abundance / biomass

604 (approximated by EVI index), estimated richness ( $\alpha$-diversity), $\beta$-diversity, and rarity (for plants 605 only).

606

\begin{tabular}{lllrr}
\hline Group & Response & Variables kept & F & P \\
\hline \multirow{2}{*}{ Spiders } & $\begin{array}{l}\text { Estimated species richness } \\
\text { ( } \alpha \text {-diversity) }\end{array}$ & Fertilisers & 4.28 & $\mathbf{0 . 0 0 8}$ \\
& Moisture & 4.45 & $\mathbf{0 . 0 0 3}$ \\
& F x VT & 1.92 & 0.101 \\
& & & \\
& & Fertilisers & 3.33 & $\mathbf{0 . 0 2 4}$ \\
& Moisture & 1.75 & 0.150 \\
& F x VT & 1.99 & 0.090 \\
& & & \\
& & & 1.59 & $\mathbf{0 . 0 2 0}$
\end{tabular}

Carabids Estimated species richness

( $\alpha$-diversity)

Abundance

Fertilisers

$1.16 \quad 0.330$

Moisture

$2.89 \quad \mathbf{0 . 0 2 8}$

F x VT

$2.11 \quad 0.074$

$\beta$-diversity

Flooding

$1.03 \quad \mathbf{0 . 0 1 0}$ 
Plants Shannon Index

( $\alpha$-diversity)

Cutting date

$0.03 \quad 0.993$

$\begin{array}{llll} & \text { Fertilisers } & 1.21 & 0.303 \\ \text { Moisture } & 7.47 & <\mathbf{0 . 0 0 1} \\ \text { EVI } & 0.03 & 0.993 \\ & \text { Fertilisers } & 1.21 & 0.303 \\ & \text { Moisture } & 7.48 & <\mathbf{0 . 0 0 1}\end{array}$

$\beta$-diversity

Fertilisers

$1.99 \quad \mathbf{0 . 0 1 0}$

Cutting date

$2.35 \quad \mathbf{0 . 0 1 0}$

Flooding

$3.51 \quad 0.010$

Moisture

$8.76 \quad \mathbf{0 . 0 1 0}$

Rarity

Moisture

5.23

0.025

607

608

609

610

611

612

613

614

615 